\title{
PENGARUH PEMAKAIAN PEG 400 DAN MENTOL DALAM PATCH MUKOADHESIF EKSTRAK ETANOL DAUN SIRIH (Piper betle L.) TERHADAP TRANSPOR SENYAWA POLIFENOL
}

\section{EFFECT OF PEG 400 AND MENTHOL TO THE POLYPHENOL COMPOUND TRANSPORT OF BETLE LEAF (Piper betle L.) EXTRACT FROM MUCOADHESIVE PATCH}

\author{
Setyawan, E.I., P. O. Samirana, I G. A. Indyayani \\ Jurusan Farmasi Fakultas Matematika dan Ilmu Pengetahuan Alam Universitas Udayana \\ Email: indrasetyawan@ymail.com
}

\begin{abstract}
ABSTRAK
Patch bukal merupakan sediaan obat dengan sistem penghantaran transmukosa. Kemampuan absorpsi zat aktif sediaan Patch bukal dapat dimodifikasi dengan penambahan suatu plasticizers dan permeation enhancer.Penelitian ini dilakukan untuk mengetahui pengaruh pemakaian PEG 400 dan mentol terhadap transpor serta mengetahui proporsi PEG 400 dan mentol yang dapat memberikan transpor optimum senyawa polifenol ekstrak daun sirih (Piper bitle L.) dari patch bukal secara in vitro. Metode yang digunakan untuk menentukan perbandingan jumlah PEG 400 dan mentol adalah dengan metode Simplex Lattice Design (SLD). Uji transpor senyawa polifenol dari patch dilakukan selama 23 jam dengan menggunakan sel difusi Franz dengan membran Whatmann No. 1. Jumlah senyawa yang tertranspor ditetapkan kadarnya dengan instrumen Spektrofotometer- $U V$. Verifikasi formula optimum dilakukan sebanyak 3 kali dengan Single Simple Test. Hasil penelitian menunjukkan bahwa penggunaan PEG 400 dan mentol dapat meningkatkan jumlah polifenol yang tertranspor. Hubungan pengaruh PEG 400 dan mentol dapat digambarkan melalui persamaan special cubic, $\mathrm{y}=3,26071(\mathrm{~A})+4,31372(\mathrm{~B})+2,80876(\mathrm{~A})(\mathrm{B})+0,64912(\mathrm{~A})(\mathrm{B})$ (A-B). Verifikasi formula optimum menghasilkan p-value 0,503(>0,05). Permodelan transpor polifenol melalui membran dapat digambarkan dengan model 4 kompartemen dan menghasilkan kecepatan masing-masing $\mathrm{L}(2,1)$ sebesar $0,013 \mathrm{mgEAG} / \mathrm{cm}^{2} / \mathrm{jam}, \mathrm{L}(3,2)$ sebesar $0,050 \mathrm{mgEAG} / \mathrm{cm}^{2} / \mathrm{jam}, \mathrm{L}(4,1)$ sebesar $0,089 \mathrm{mgEAG} / \mathrm{cm}^{2} / \mathrm{jam}$, dan L $(3,4)$ sebesar $0,027 \mathrm{mgEAG} / \mathrm{cm}^{2} / \mathrm{jam}$.
\end{abstract}

Kata kunci: Piper betle, mentol, Patch bukal, PEG 400, polifenol. 


\begin{abstract}
Buccal patch is one of the transmucosal delivery system. The ability of drug absorption could modify by using plasticizer and permeation enhancer. This research is aim to find the effect of PEG 400 and Menthol to polyphenol transport and to find the proportion of each substance that could give the optimum polyphenol transport. The comparison of PEG 400 and Menthol is determined by using Simplex Lattice Design (SLD) Method. Transport test was performed by Franz Diffusion Cell with Membrane Whatman No.1 for 23 hours. The number of compounds that are transported set by using Spectrophotometer-UV. Optimization of the formula is performed by SLD and the verification of its performed by Single Simple Test.The result show that by using PEG 400 and Menthol could increasing the transport of Polyphenol compound. The relation of its could be conceived by special cubic equation, $y=3.26071(A)+4.31372(B)$ $+2.80876(A)(B)+0.64912(A)(B)(A-B)$. The verification of formula optimum have p-value 0.511(>0.05). Modeling of the polyphenol transport through the membrane could be conceived by 4-Compartement model and the speed of transport are $L(2.1)=0.013 \mathrm{mgGAE} / \mathrm{cm}^{2} / \mathrm{h}, \quad L(3.2)=0.050 \mathrm{mgGAE} / \mathrm{cm}^{2} / \mathrm{h}$, $L(4.1)=0.089 \mathrm{mg} / \mathrm{cm}^{2} / \mathrm{h}$, and $L(3.4)=0.027 \mathrm{mgGAE} / \mathrm{cm}^{2} / \mathrm{h}$.
\end{abstract}

Keywords: Piper betle, Menthol, Buccal patch, PEG 400, Polyphenol.

\title{
PENDAHULUAN
}

Patch bukal merupakan sediaan obat dengan sistem penghantaran transmukosa. Kelebihan patch bukal dibandingkan bentuk sediaan obat lain adalah tidak melalui tahap first pass metabolism, penggunaannya dapat dihentikan hanya dengan melepaskan sediaan dari tempat permukaan mukosa, penghantaran obat dapat dikontrol lebih lama, serta kemampuan absorpsi zat aktif dapat dimodifikasi dengan penambahan suatu plasticizers dan permeation enhancer (Pathan and Setti, 2009). Ditinjau dari cara pembuatannya terdapat dua jenis patch yaitu, membrane controlled dan matrix controlled. Sistem matriks memiliki beberapa keuntungan, yaitu memiliki bentuk yang lebih kecil dan lebih tipis, serta dapat mengurangi resiko overdosis dibandingkan patch dengan sistem membrane (Margetts and Sawyer, 2007).

Sediaan patch dapat bekerja secara efektif jika zat aktifnya dapat berpenetrasi ke bagian bawah mukosa, sehingga diperlukan plasticizer dan permeation enhancer untuk memperbaiki bioavailabilitas obat yang sulit menembus lapisan 
mukosa bukal. PEG 400 dapat digunakan sebagai plasticizer karena mampu meningkatkan pelepasan obat dengan mengubah permeabilitas membran menjadi lebih hidrofilik (Jinghua et al., 2001). Mentol dapat digunakan sebagai permeation enhancer dikarenakan mentol mampu meningkatkan solubilitas dari bahan obat serta mampu meningkatkan difusi obat dengan mengganggu urutan konformasi lipid intercellular pada lapisan bilayer mukosa (Wu et al.,2012). Hasil penelitian Jia et al. (2007) menunjukkan, penggunaan senyawa terpen seperti mentol mampu menghantarkan senyawa polifenol seperti katekin dengan fluks sebesar 216,24 nmol/cm²/jam, sehingga penggunaan PEG 400 sebagai plasticizer dan mentol sebagai permeation enhancer dalam patch bukal dapat meningkatkan transpor obat ke dalam mukosa bukal.

Patch bukal dapat diaplikasikan untuk mengatasi salah satu masalah kesehatan di dalam mulut yaitu, gingivitis. Senyawa polifenol pada ekstrak $P$. betle dapat berfungsi sebagai antibakteri dan antiinflamasi yang merupakan penyebab dari penyakit gingivitis akut (ANUG) dengan symptoms lymphadenopathy atau demam, sehingga sediaan patch bukal ekstrak etanol daun sirih dimanfaatkan untuk tujuan sistemik (Subashkumar et al, 2013; Palaska et al., 2013).Berdasarkan hal tersebut penelitian ini bertujuan untuk mengetahui pengaruh penggunaan kombinasi PEG 400 sebagai plasticizer dengan mentol sebagai permeation enhancer terhadap transpor polifenol dari matriks sediaan patch ekstrak etanol P. betle.

\section{METODE PENELITIAN}

Bahan-bahan tambahan yang digunakan dalam formula patch berderajat teknis dan pereaksi yang digunakan berderajat pro-analisis.

\section{Pembuatan Ekstrak P. betle}

Ekstraksi $P$. betle dilakukan dengan metode maserasi dengan pelarut etanol $96 \%$ selama 24 jam. Filtrat kemudian diuapkan dengan bantuan rotary evaporator berkecepatan $60 \mathrm{rpm}$ pada suhu $50^{\circ} \mathrm{C}-60^{\circ} \mathrm{C}$. 
Uji Kandungan Polifenol

Uji kandungan polifenol dilakukan dengan menambahkan 5 tetes $\mathrm{NaCl} 10 \%$ ke dalam ekstrak, kemudian larutan dibagi menjadi 2 bagian ke dalam tabung reaksi yang berbeda. Tabung reaksi pertama ditambahkan 3 tetes $\mathrm{FeCl}_{3} 1 \%$, kemudian didiamkan selama beberapa saat.Terjadinya perubahan warna menjadi warna hijau kehitaman, menandakan adanya senyawa fenolik dan tanin yang terkandung dalam sampel tersebut.

\section{Penetapan Kadar Total Polifenol}

Penetapan kadar polifenol dalam ekstrak dilakukan dengan menggunakan senyawa pembanding asam galat dan pereaksi Folin-Ciocalteu. Kadar ditetapkan dengan menggunakan metode Spektrofotometri UV-Vis. Absorbansi maksimum senyawa polifenol ditentukan pada panjang gelombang $742 \mathrm{~nm}$, dengan operating time 20 menit. Kurva baku ditentukan dengan mereaksikan larutan asam galat konsentrasi 5, 10, 15, 20, 25, 30, 35 dan 40 $\mathrm{g} / \mathrm{mL}$ dengan reagen Folin-Ciocalteu (1:10) dan digojog dan didiamkan selama 3 menit. Masing-masing larutan ditambahkan $1 \mathrm{~mL}$ larutan $\mathrm{Na}_{2} \mathrm{CO}_{3}$ 7,5\%. Didiamkan selama operating time pada suhu kamar. Absorbansi diukur pada panjang gelombang maksimum, kemudian dibuat kurva kalibrasi hubungan antara konsentrasi asam galat dengan absorbansi. Ekstrak etanol $P$. betle diambil sebanyak 10,0 mg dan dilarutkan dengan etanol hingga volume 10,0 mL. Larutan ekstrak yang diperoleh dilakukan pemipetan $250 \mu \mathrm{L}$ diperlakukan sama dengan cara penentuan kurva kalibrasi. Data yang diperoleh dari hasil pengukuran adalah berupa absorbansi, yang kemudian kadar senyawa fenolik dalam sampel dihitung dengan bantuan persamaan yang diperoleh dari pembuatan kurva baku dengan standar asam galat yang telah dilakukan sebelumnya.

Formulasi Matriks Patch

Pembuatan matriks patch dilakukan dengan sistem matriks. Masingmasing Run dibuat dengan volume $17 \mathrm{~mL}$ (Tabel I). 
Tabel I. Formula matriks patch

\begin{tabular}{|c|c|c|c|c|}
\hline Run & $\begin{array}{l}\text { Ekstrak Etanol } \\
\text { Daun Sirih (mL) }\end{array}$ & $\begin{array}{c}\text { HPMC } 3 \% \mathrm{~b} / \mathrm{v} \\
(\mathrm{mL})\end{array}$ & $\begin{array}{c}\text { Menthol 1\% } \\
(\mathrm{mL})\end{array}$ & $\begin{array}{l}\text { PEG 400 } \\
(\mathrm{mL})\end{array}$ \\
\hline 1 & $5,0^{*}$ & 10,0 & 0,0 & 2,0 \\
\hline 2 & $5,0^{*}$ & 10,0 & 0,0 & 2,0 \\
\hline 3 & $5,0^{*}$ & 10,0 & 1,0 & 1,0 \\
\hline 4 & $5,0^{*}$ & 10,0 & 1,5 & 0,5 \\
\hline 5 & $5,0^{*}$ & 10,0 & 1,0 & 1,0 \\
\hline 6 & $5,0^{*}$ & 10,0 & 0,5 & 1,5 \\
\hline 7 & $5,0^{*}$ & 10,0 & 2,0 & 0,0 \\
\hline 8 & $5,0^{*}$ & 10,0 & 2,0 & 0,0 \\
\hline
\end{tabular}

\section{Uji Transpor Senyawa Polifenol dari Matriks Patch Bukal}

Uji transpor patch dilakukan secara in-vitro dilakukan dengan alat Franz Difusion Cell. Kertas Whatman No. 1 yang telah direndam di dalam larutan dapar fosfat salin (PBS) diletakkan di antara kompartemen donor dan reseptor. Kompartemen reseptor diisi larutan PBS 0,1 M pH 7,4 sebesar 50,0 mL. Patch diletakkan diantara kompartemen donor dan kompartemen reseptor. Pada kompartemen reseptor dilakukan pengadukan menggunakan magnetic bar dengan kecepatan $60 \mathrm{rpm}$ dan dipertahankan pada suhu $31^{\circ} \mathrm{C}$.

Pengamatan dilakukan selama 23 jam, dengan pengambilan sampel masingmasing 1,0 mL pada menit ke-15, 30, 45 dan dilanjutkan pada 7 jam pertama dan 3 jam terakhir. Setiap pengambilan sampel, kekurangan volume reseptor diganti dengan larutan PBS pH 7,4 yang baru sebanyak sampel yang diambil dengan suhu yang sama. Prosedur yang dilakukan untuk menetapkan kadar polifenol yang tertranspor sama seperti yang dilakukan pada prosedur penetapan kadar fenolik total dalam ekstrak.

Optimasi Jumlah PEG 400 dan Mentol

Penentuan jumlah PEG 400 dan mentol yang optimal dilakukan dengan melihat hasil uji transport senyawa polifenol matriks patch bukal pada masingmasing formula dimana dalam uji transpor senyawa polifenol matriks patch bukal tersebut ditentukan formula yang menghasilkan jumlah kumulatif senyawa fenolik 
yang terlepas paling besar. Metode yang digunakan adalah Simplex Lattice Design. Data yang diperoleh berupa nilai prediksi jumlah kumulatif senyawa polifenol yang tertranspor paling besar.

\section{Verifikasi Hasil}

Verifikasi dilakukan dengan membandingkan jumlah rata-rata senyawa polifenol yang tertranspor pada percobaan hasil optimasi dengan hasil prediksi oleh model. Proses verifikasi tersebut dilakukan dengan menggunakan uji T-test (single simple test).

\section{HASIL DAN PEMBAHASAN}

Hasil ekstraksi dengan metode maserasi dengan pelarut etanol $96 \%$ ekstrak kental yang diperoleh sebanyak 32,61 gram dari 300 gram serbuk simplisia. Rendemen yang diperoleh sebesar 10,69\%. Etanol 96\% digunakan sebagai pelarut karena memiliki resiko toksisitas rendah, sehingga dapat digunakan sebagai pelarut ekstrak pada sediaan patch bukal (International Conference on Harmonisation, 2012).

Ekstrak daun sirih pada percobaan ini dinyatakan mengandung senyawa polifenol. Hasil positif diperlihatkan dengan adanya perubahan warna menjadi semakin hijau kehitaman ketika setelah direaksikan dengan $\mathrm{FeCl}_{3} \quad 1 \%$. Pembentukan komplek berwarna biru kehitaman tersebut diprediksikan terjadi reaksi kompleksasi pada C-3 dan C-5 gugus hidroksil pada cincin B dengan $\mathrm{Fe}(\mathrm{III})$ seperti yang terjadi pada senyawa polifenol golongan flavonoid (flavonols) (Anna and Krystyana, 2014).

Hasil penetapan kadar total senyawa polifenol dalam $P$. betle didapatkan kadar total fenoliknya sebesar 57,2 mg.GAE/g. Kadar total senyawa polifenol yang diperoleh berbeda dengan kadar yang dari penelitian Putri dan Farida (2013) yaitu sebesar $1,17 \%$. Hal ini disebabkan oleh $P$. betle yang digunakan dari daerah yang berbeda akan menghasilkan jumlah metabolit sekunder yang berbeda pula. Kadar kandungan metabolit sekunder dapat dipengaruhi oleh daerah tumbuh 
tanaman, usia tanaman, dan ketebalan daun. Selain itu, cara pengolahan terutama proses pengeringan (suhu, aktivitas UV, kelembapan) juga mempengaruhi kandungan metabolit sekunder suatu tanaman (Rostiana, dkk., 1992; Hernani dan Nurdjanah, 2009; Kridati, dkk., 2012).

Uji Transpor Senyawa Polifenol dari Matriks Patch Bukal

Jumlah kumulatif senyawa polifenol yang tertranspor pada jam ke-23 tersaji pada Tabel II.

Tabel II. Jumlah kumulatif senyawa polifenol yang tertranspor pada jam ke-23 dengan penggunaan proporsi mentol dan PEG 400 yang berbeda

\begin{tabular}{|c|c|c|c|}
\hline Run & $\begin{array}{l}\text { Mentol 1\% } \\
\quad(\mathrm{mL})\end{array}$ & $\begin{array}{c}\text { PEG 400 } \\
(\mathrm{mL})\end{array}$ & $\begin{array}{c}\text { Jumlah kumulatif } \\
\text { pada jam ke-23 } \\
(\text { mgEAG/cm })\end{array}$ \\
\hline 1 & 0,00 & 2,00 & 8,57 \\
\hline 2 & 0,00 & 2,00 & 8,67 \\
\hline 3 & 1,00 & 1,00 & 10,25 \\
\hline 4 & 0,50 & 1,50 & 9,71 \\
\hline 5 & 1,00 & 1,00 & 10,42 \\
\hline 6 & 1,50 & 1,50 & 9,79 \\
\hline 7 & 2,00 & 0,00 & 6,37 \\
\hline 8 & 2,00 & 0,00 & 6,66 \\
\hline
\end{tabular}

Hasil fitting kurva profil hubungan antara PEG 400 dan mentol terhadap transpor senyawa polifenol yang ditunjukkan oleh Gambar 1, terlihat bahwa terjadi peningkatan jumlah senyawa polifenol yang tertranspor ketika PEG 400 dan mentol dikombinasikan. Penurunan jumlah senyawa polifenol yang tertranspor terjadi seiring peningkatan jumlah komponen PEG 400 tanpa adanya penambahan mentol, serta penurunan jumlah senyawa polifenol juga terjadi karena adanya peningkatan jumlah komponen mentol tanpa kombinasi dengan PEG 400. 


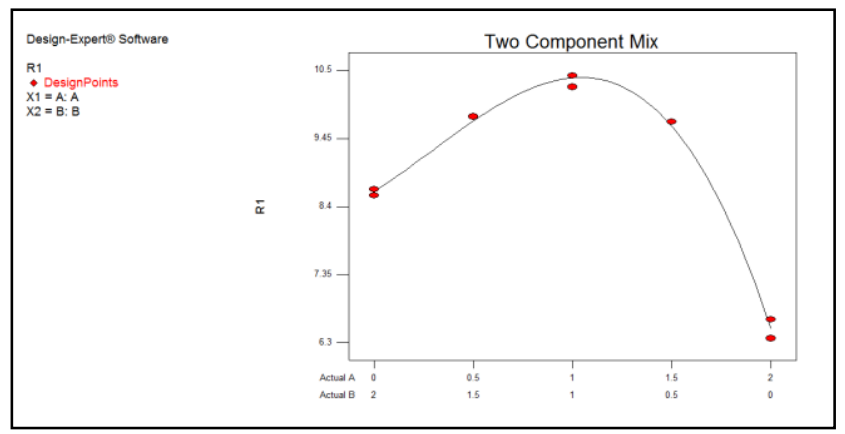

Gambar 1. Grafik Hubungan antara komposisi campuran PEG 400 dan mentol jumlah kumulatif senyawa polifenol yang tertranspor dari matriks patch bukal.

Keterangan : Sumbu $y$ merupakan respon yang dihasilkan

Sumbu $x$ merupakan komponen PEG 400 dan mentol

Pengaruh PEG 400 dan mentol terhadap transpor senyawa polifenol dapat dirumuskan melalui persamaan bentuk cubic dari simplex lattice design (actual component).

$$
y=3,26071(A)+4,31372(B)+2,80876(A)(B)+0,64912(A)(B)(A-B)
$$

Keterangan : $y=$ jumlah kumulatif senyawa polifenol yang tertranspor (mg.EAG/g)

$\mathrm{A}=$ proporsi komponen mentol

$\mathrm{B}=$ proporsi komponen $\mathrm{PEG} 400$

Persamaan tersebut memiliki nilai probabilitas lack of fit sebesar 0,463 $(p>0,05)$ dengan uji ANOVA sehingga perbedaan yang muncul antara model persamaan hasil prediksi dengan hasil observasi tidak berbeda signifikan. Nilai probabilitas 0,0001 $(p<0,05)$ menandakan bahwa model persamaan yang digunakan mampu menggambarkan kondisi aktual jumlah kumulatif senyawa polifenol dari matriks patch.

Pengaruh PEG 400 dalam peningkatan jumlah senyawa polifenol tertranspor disebakan oleh karena sifat PEG 400 yang dapat mengubah permeabilitas membran menjadi lebih hidrofilik (Jinghua et al., 2001) sehingga pelepasan senyawa polifenol menjadi semakin besar. Selaras dengan PEG 400, mentol dapat meningkatkan solubilitas daribahan obat serta mampu meningkatkan difusi obat dengan mengganggu urutan konformasi lipid intercellular pada lapisan bilayer mukosa (Wu et al.,2012). Hasil tersebut diperkuat dengan hasil penelitian Jia et al. (2007), menunjukkan bahwa penggunaan senyawa terpen seperti mentol 
mampu menghantarkan senyawa polifenol seperti katekin dengan fluks sebesar $216,24 \mathrm{nmol} / \mathrm{cm}^{2} / \mathrm{jam}$ jauh lebih besar dengan tanpa menggunakan permeation enhancer.

Hasil prediksi dihasilkan formula optimal dengan perbandingan mentol:PEG400 (1,043:0,957) yang memiliki nilai desirability sebesar 0,992 .

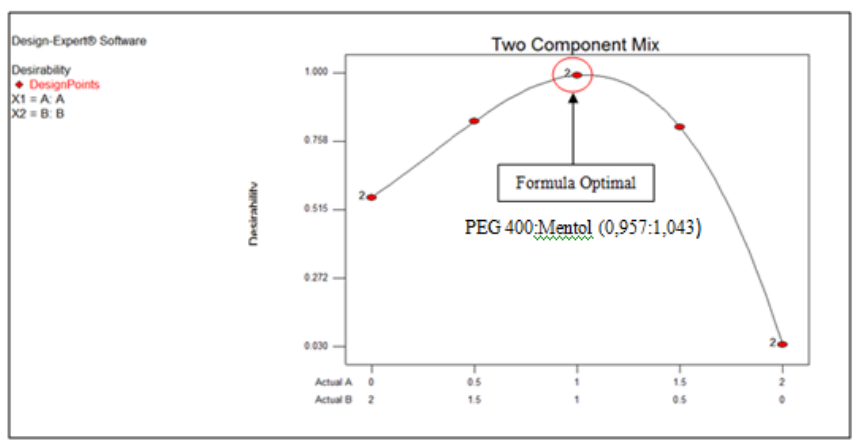

Gambar 2. Grafik Hubungan antara Komponen PEG 400 dan Mentol terhadap Nilai Desirability

Keterangan : Sumbu y merupakan nilai desirability

Sumbu $x$ merupakan komponen PEG 400 dan mentol

\section{Verifikasi Hasil}

Berdasarkan hasil percobaan diperoleh nilai dari masing-masing respon seperti pada Tabel III. Respon yang diamati adalah jumlah kumulatif senyawa polifenol yang tertranspor dari matriks patch $\left(\mathrm{mgEAG} / \mathrm{cm}^{2}\right)$.

Tabel III. Hasil verifikasi formula

\begin{tabular}{lccc}
\hline \multicolumn{1}{c}{ Respon yang diamati } & $\begin{array}{c}\text { Hasil Observasi } \\
\text { Rata-rata } \pm \text { SD }\end{array}$ & Nilai Teoritis & p-value \\
\hline $\begin{array}{l}\text { Jumlah kumulatif senyawa polifenol } \\
\text { tertranspor }\left(\mathrm{mgGAE} / \mathrm{cm}^{2}\right)\end{array}$ & $1042 \pm 0,07$ & 10,388 & 0,511 \\
& & & \\
\hline
\end{tabular}

Keterangan : perhitungan $p$-value diperoleh dengan menggunakan single simple test

Nilai probabilitas respon yang lebih besar dari 0,05 berarti hasil prediksi dengan hasil observasi percobaan tidak ada perbedaan yang bermakna. 
Penentuan Kecepatan Transpor dengan WINSAAM

WinSAAM (A Windows-Based Compartmental Modeling System) merupakan metode yang sesuai untuk menjelaskan farmakokinetika sistem kompartemen. Sebuah kompartemen harus teridiri dari senyawa yang homogen atau secara kinetika tidak dibedakan dari senyawa lain dalam kompartmen (Stefanovski et al, 2003).

Model kompartemen yang digunakan adalah model kompartemen yang sesuai dengan transpor senyawa polifenol yaitu model empat kompartemen, dengan skema model dapat dilihat pada Gambar 2.

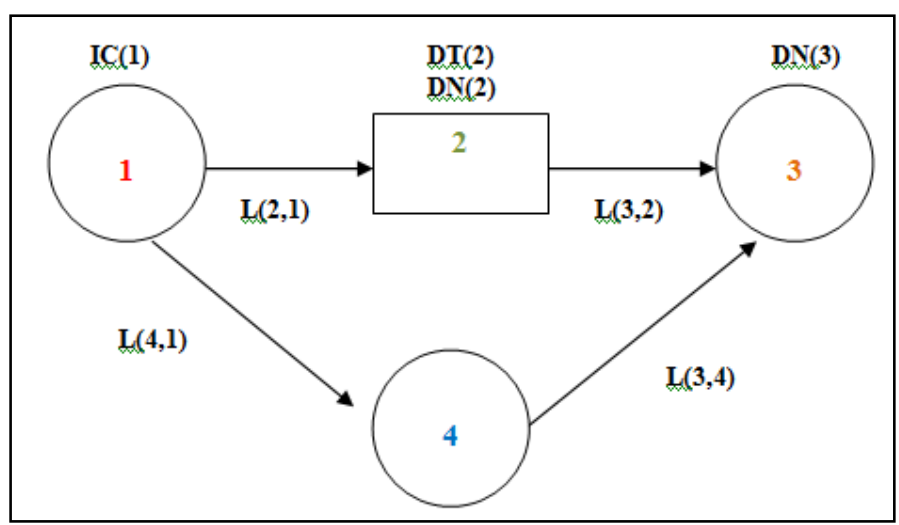

Gambar 3. Skema Model Transpor Transmukosa Menggunakan Pendekatan Empat Kompartemen

Keterangan IC(1) : jumlah obat yang siap untuk ditranspor dalam kompartemen (kompart) 1

$\mathrm{L}(2,1)$ : konstanta kecepatan transpor dari kompart. 1 menuju ke kompart. 2

$\mathrm{L}(3,2)$ : konstanta kecepatan transpor dari kompart. 2 menuju ke kompart. 3

$\mathrm{L}(4,1)$ : konstanta kecepatan transpor dari kompart. 1 menuju ke kompart. 4

L $(3,4)$ : konstanta kecepatan transpor dari kompart. 4 menuju ke kompart. 3

DT(2) : kompart. lag (lamanya obat tertahan pada kompart. 2)

$\mathrm{DN}(2)$ : Nilai yang menggambarkan berapa banyak kompart. lag yang ada pada sebuah model

Fitting kurva dilakukan dengan memodifikasi dari setiap parameter pada keterangan Gambar 3 hingga diperoleh kurva yang sesuai antara jumlah obat yang tertranspor hasil observasi dan jumlah obat yang tertranspor hasil prediksi. Model 4 kompartemen seperti pada Gambar 3 menggambarkan kompartemen 1 (IC) merupakan kompartemen obat yang siap untuk ditranspor, kompartemen 2 merupakan jalur transeluler, kompartemen 3 merupakan sirkulasi sistemik, dan 
kompartemen 4 merupakan jalur paraseluler. Permodelan kompartemen digunakan karena dapat menggambarkan fluks sebagai fungsi dari waktu.

Tabel IV. Data parameter transpor senyawa polifenol dari matriks patch bukal

\begin{tabular}{|c|c|c|c|c|}
\hline \multicolumn{5}{|c|}{ Parameter } \\
\hline $\begin{array}{c}\text { DT(2) } \quad\left(\text { jam }^{-1}\right) \\
(X \pm \text { SD })\end{array}$ & $\begin{array}{c}\mathrm{L}(2,1)(\mathrm{mg} / \mathrm{jam}) \\
(X \pm \mathrm{SD})\end{array}$ & $\begin{array}{c}\mathrm{L}(3,2)(\mathrm{mg} / \mathbf{j a m}) \\
(X \pm \mathrm{SD})\end{array}$ & $\begin{array}{c}\mathrm{L}(4,1)(\mathrm{mg} / \mathrm{jam}) \\
(X \pm \mathrm{SD})\end{array}$ & $\begin{array}{c}\mathrm{L}(3,4)(\mathrm{mg} / \mathrm{jam}) \\
(X \pm \mathrm{SD})\end{array}$ \\
\hline $0,3215 \pm 0,28$ & $0,0133 \pm 0,01$ & $0,0500 \pm 0,00$ & $0,0897 \pm 0,04$ & $0,0269 \pm 0,02$ \\
\hline
\end{tabular}

Proses fitting kurva (Gambar 3) menunjukkan bahwa terdapat dua kompartemen lag pada model transpor dari matriks patch bukal, yang artinya ada dua jalur umum yang dilewati oleh obat untuk menembus lapisan mukosa. Jalur tersebut adalah jalur transcellular (intracellular) dan jalur paracellular (intercellular), hal ini disebakan karena senyawa polifenol ada yang bersifat hidrofobik dan ada yang bersifat hidrofilik. Ruang intercellular berperan sebagai barier utama dalam permeasi senyawa yang bersifat lipofilik dan membran sel berperan sebagai barier intracellular untuk senyawa yang bersifat hidrofilik. Jalur utama tranpor senyawa polifenol adalah jalur paraseluler, hal ini dikarenakan jalur paraseluler tidak melalui lag time yang berarti, yang mana hal ini ditunjukkan oleh Tabel IV yang mencantumkan bahwa kecepatan terbesar terdapat jalur paraseluler yaitu sebesar $0,0897 \mathrm{mgEAG} / \mathrm{cm}^{2} / \mathrm{jam}$.

\section{KESIMPULAN}

Penggunaan PEG 400 dan mentol dapat meningkatkan jumlah senyawa polifenol yang tertranspor. Perbandingan komposisi PEG 400 dan mentol 0,957:1,043 menghasilkan transpor senyawa polifenol dari matriks patch bukal yang optimal dengan prediksi jumlah senyawa yang tertranspor sebesar 10,388 $\mathrm{mgEAG} / \mathrm{cm}^{2}$ dan kecepatan transpor melalui jalur transeluler sebesar 0,013 $\mathrm{mgEAG} / \mathrm{cm}^{2} / \mathrm{jam}$ dan melalui jalur paraseluler sebesar $0,089 \mathrm{mgEAG} / \mathrm{cm}^{2} / \mathrm{jam}$. 


\section{UCAPAN TERIMAKASIH}

Kepada Universitas Udayana melalui dana PNBP yang telah memberikan bantuan dana penelitian beserta segenap anggota penelitian yang ikut berkontribusi dalam penulisan karya tulis ini.

\section{DAFTAR PUSTAKA}

Anna, P., and Krystyana, P., 2014, Evaluation of Aluminium Complexation Reaction for Falavonoid Content Assay, Food Anal. Methods, (7) : 17761782.

Hernani dan R. Nurdjanah, 2009, Aspek Pengeringan dalam Mempertahankan Kandungan Metabolit Sekunder pada Tanaman Obat, Perkembangan Teknologi TRO, 21 (2) : 33-39.

International Conference on Harmonisation, 2012, Guidance for Industry, International Conference on Harmonisation, USA : 3-7.

Jia-You FANG, Tung-Hu TSAI, Yu-Ying LIN, Wen-Wen WONG, Meng-Nan WANG, and Jeng-Fen HUANG, 2007, Transdermal Delivery of Tea Catechins and Theophylline Enhanced by Terpenes: a Mechanistic Study, Bio.Pharm. Bull., 30(2), 343-349.

Jinghua,Y., S. Peter, and H. Stephen, 2001, Effect of Polyethylen Glycol on Morphology Thermomechanical Properties and Water Vapor Permeability of Cellulose Acetate Free Film, Pharm.Tech., 423 : 62-73.

Kridati, E. M., E. Prihastanti, dan S. Haryanti, 2012, Rendemen Minyak Atsiri dan Diameter Organ serta Ukuran Sel Minyak Tanaman Adas (Foeniculum vulgare Mill) yang Dibudidayakan di Kabupaten Semarang dan Kota Salatiga, Buletin Anatomi dan Fisiologi, 20 (1) : 1-17.

Margetts, Lyn and R. Sawyer, 2007, Transdermal Drug Delivery: Principles and Opioid Therapy, The Board of Management and Trustees of the British Journal of Anaesthesia, 7 (5) : 171-175.

Palaska, I., E. Papathanasiou, T. C. Theoharides, 2013, Use of polyphenol in Periodontal Inflammation, Eur.J.Pharmacol., 720 : 77-83.

Pathan, I.B. and C.M. Setty, 2009, Chemical Penetration Enhancers for Transdermal Drug Delivery Systems. Trop.J.Pharm.Res., 8(2) : 173-179. 
Putri, T.A. dan Farida, Y., 2013, Total Phenolic, Flavonoids Content and Antioxidant Activity of The Ethanolic Extract of Betel Leaf (Piper betle L.), The International Conference in Nanotechnology in Jakarta.

Rostiana, O., S.M. Rosita, dan D. Sitepu, 1992, Keanekaragaman Genotipa Sirih (Piper betle L.) Asal dan Penyebaran, Warta Tumbuhan Obat Indonesia, 1 (1).

Setyawan, E.I., Dewantara, I.G.N.A., Putra, I.M.D.D., 2014, Optimasi Formula Matrik Patch Mukoadhesif Ekstrak Daun Sirih (Piper betle L.) Menggunakan Mentol Dan PEG 400 Sebagai Permeation Enhancer Dan Plasticizer, Media Farmasi UAD, 11 (2) : 120-132.

Stefanovski D. Peter J. M. dan Raymond C. B, 2003, WinSAAM: A WindowsBased Compartmental Modeling System, Metabolism, 52 (9) : 1153-1166.

Subashkumar, R., Sureshkumar, M., Babu, S., and Thayumanavan, T., 2013, Antibacterial Effect of Crude Aqueous Extract of Piper betle L. Against Pathogenic Bacteria, Int. J. Res. Pharm. Biomed. Sci., 4 (1) : 42-46.

Wu, X., Desai, K.G.H., Mallery, S.R., Hulpoch, A.S., Pelps, M.P., and Schwendeman, S.P., 2012, Mucoadhesive Fenretinide Patches for Sitespecific Chemoprevention of Oral Cancer: Enhancement of Oral Mucosal Permeation of Fenretinide by Co-incorporation of Propylene Glycol and Menthol, Mol. Pharm., 9 (4) : 937-945. 